\title{
Assessment of $\alpha$-tocopherol content in cow and goat milk from the Serbian market
}

\author{
Slavica Sunarić ${ }^{1}$, Jelena Živković ${ }^{1}$, Radmila Pavlović ${ }^{1}$, Gordana Kocić ${ }^{2}$, Nataša Trutić $^{1}$, Slavoljub Živanović ${ }^{3}$ \\ ${ }^{1}$ University of Niš, Faculty of Medicine, Department of Chemistry, Niš, Serbia \\ ${ }^{2}$ University of Niš, Department of Biochemistry, Faculty of Medicine, Niš, Serbia \\ ${ }^{3}$ University of Niš, Faculty of Medicine, Laboratory for Chromatography, Niš, Serbia
}

\begin{abstract}
The present paper reports determination of $\alpha$-tocopherol in commercial cow, raw cow and goat milk, as well as an estimation of its nutritive value based on $\alpha$-tocopherol content. The quantification was done by reversed-phase HPLC with fluorescence detection (ex 295 $\mathrm{nm}$, em $330 \mathrm{~nm}$ ) and with UV detector set at 286 and $292 \mathrm{~nm}$. The method of milk sample preparation consisted of alkaline saponification with $30 \% \mathrm{KOH}$, denaturation of lipoproteins with methanol followed by liquid-liquid extraction with diethyl ether. Recovery values of the extraction method were $78.5,86.7$ and $91.0 \%$ for three standard addition levels. Analyzed commercial low-fat milk samples had significant lower $\alpha$-tocopherol levels than milk with higher fat content. $\alpha$-tocopherol concentrations below $0.30 \mu \mathrm{g} / \mathrm{ml}$ in low-fat cow milk and $0.83-0.86 \mu \mathrm{g} / \mathrm{ml}$ in whole milk were detected. Raw goat milk had much more $\alpha$-tocopherol $(1.25 \mu \mathrm{g} / \mathrm{ml})$ compared with commercial and raw cow milk with similar fat content.
\end{abstract}

Keywords: $\alpha$-tocopherol, cow milk, goat milk, HPLC analysis.

\section{SCIENTIFIC PAPER}

UDC 637.12(497.11):543.645.5:543.544

Hem. Ind. 66 (4) 559-566 (2012)

doi: 10.2298/HEMIND111116006S

Available online at the Journal website: http://www.ache.org.rs/HI/

One of the major fat-soluble vitamins and antioxidants in milk is vitamin E. The term vitamin E is used for a family of eight molecules of related structure. All of these molecules possess antioxidant activity, although $\alpha$-tocopherol is chemically and biologically the most active. $\alpha$-Tocopherol reacts with fatty acid peroxyl radicals, the primary products of lipid peroxidation, and intercepts the chain reaction [1]. Therefore, it is an important component of the cellular defense system and protects the cell membrane and cell content from oxidative damage. Vitamin $E$ is only biosynthesized by plants and distributed in milk principally as $\alpha$-tocopherol. Naturally occurring antioxidants have a potential for use as components in functional foods or nutraceutical which are fortified, enriched or enhanced with particular compounds. $\alpha$-Tocopherol is often added to milk for a number of purposes: to restore its content where this has been reduced during technological, storage or handling procedures, to enhance nutritive value or to prevent lipid oxidation, reaction which leads to oxidative rancidity of milk and dairy products. For this purpose, Regulation (EC) No 1925/2006 of the European Parliament and of the Council allows addition of $\alpha$-tocopherol, $\alpha$-tocopheryl acetate and $\alpha$-tocopheryl acid succinate [2]. $\alpha$-Tocopheryl acetate is one of the

Correspondence: S. Sunarić, Department of Chemistry, Faculty of Medicine, University of Niš, Bulevar Zorana Djindjica 81, 18000 Niš, Serbia.

E-mail: ssunaric@medfak.ni.ac.rs

Paper received: 16 November, 2011

Paper accepted: 25 January, 2012 main forms of vitamin $E$ present in dietary supplements, because it is more stable and less oxidabile than $\alpha$-tocopherol. $\alpha$-Tocopheryl acetate carries an acetyl group esterified at the C- 6 hydroxyl to increase its stability, but this also blocks antioxidant properties. Ester hydrolysis is achieved by pancreatic esterases, which release free alcohol form that is subsequently absorbed in the small intestine [3]. Vitamin E supplementation of animal diets at the dairy farms is very important because it prevents many animal diseases, which can affect milk quality. Manipulation of the animal's diet can result in increase of the concentration of some essential nutrients (e.g., vitamin E) in milk [4].

Because of the significant antioxidant properties and in order to maintain optimal daily intake of this essential factor in human nutrition, it is important to control $\alpha$-tocopherol levels in milk. To determine $\alpha$-tocopherol in milk different analytical procedures were proposed. Nowadays, the most frequently used are HPLC techniques with UV or fluorescence detection, which are various with respect to the procedure of preparing samples and mobile phase [5-15].

In addition to usual consumed milk, milk supplemented with vitamin $\mathrm{E}$ can be found in the stores. In these cases, the amount of vitamin $E$ in the product is clearly labeled and declared by the manufacturer. To our knowledge, there are no data on the amount and comparison of $\alpha$-tocopherol levels in unsupplemented pasteurized and UHT milk in domestic market. For that reason, the aim of our work was to determine and compare the quantity of $\alpha$-tocopherol in unsupple- 
mented commercial cow milk frequently consumed in Serbia and raw cow and goat milk from rural area near the city of Niš.

\section{EXPERIMENTAL}

\section{Materials and reagents}

Stock standard solution of $\alpha$-tocopherol $(0.908$ $\mathrm{mg} / \mathrm{ml}$ ) was prepared by dissolving $( \pm)$ - $\alpha$-tocopherol (Fluka Analytical BioChemika 1.1 units/mg) in absolute ethanol. Stock standard solution of $\alpha$-tocopheryl acetate $(1.27 \mathrm{mg} / \mathrm{ml})$ was obtained by dissolving standard of $\alpha$-tocopheryl acetate (Fluka Analytical BioChemika 1.00 units $/ \mathrm{mg}$ ) in absolute ethanol. The solutions were stored at $4{ }^{\circ} \mathrm{C}$ in light-resistant glass bottles. Working solutions $(100 \mu \mathrm{g} / \mathrm{ml})$ were prepared daily from the stock standard solutions.

For saponification and extraction $10 \% \mathrm{KOH}, 30 \%$ $\mathrm{KOH}, 50 \% \mathrm{KOH}$, methanol, $0.5 \%$ ascorbic acid and diethyl ether were used.

HPLC grade methanol and acetonitrile were obtained from Merck (Darmstadt, Germany). All other reagents were of analytical grade.

\section{Apparatus and HPLC conditions}

The Agilent Technologies 1200 Series apparatus with DAD and FL detection was used for the analysis. For monitoring of chromatographic system and data acquisition, Agilent Chem Station software was used.

The final selected chromatographic conditions were: Restek Ultra IBD C18 analytical column, mobile phase $100 \%$ ACN at isocratic mode with the flow rate of 2 $\mathrm{ml} / \mathrm{min}$, and column temperature of $40{ }^{\circ} \mathrm{C}$. In some milk samples low quantity of $\alpha$-tocopherol may be expected. Therefore, the fluorescence detector was used because it provided higher sensitivity and selectivity than UV detector. Detection was made at excitation and emission wavelengths at 295 and $330 \mathrm{~nm}$, respectively.

\section{Analytical procedures}

Chromatographic peaks obtained for the sample were identified by comparing its retention times and UV spectra with those of standard substances. Quantification of $\alpha$-tocopherol was done by method of calibration graph. In order to obtain calibration curve, a series of $\alpha$-tocopherol standard solutions in the concentration range of $0.3-2.0 \mu \mathrm{g} / \mathrm{ml}$ was prepared. From these solutions $20 \mu \mathrm{l}$ was injected into column. Each solution was injected 5 times. The calibration curve was constructed by plotting the peak area of the analyte against its concentration.

\section{Sample collection}

Fifteen different samples of pasteurized and UHT unsupplemented cow milk of most representative pro- ducers in Serbia were purchased from local shops. Fifteen samples of raw cow milk and fifteen samples of raw goat milk were collected from the same mountainous area near the city of Niš in the summer and winter period. Commercial pasteurized and UHT milk had different fat content labeled by the producers. All milk samples were first analyzed by measuring the milk fat according to the standard Gerber method [16].

\section{Statistical analysis}

Statistical analysis was carried out using Statistica v. 6.0 (StatSoft Inc., Tulsa, OK, USA). Pearson correlation test was conducted to determine the correlation among variables. Significant levels were defined at $p<0.05$. All experiments were performed at least in triplicate. The results are presented as mean value \pm SD.

\section{RESULTS AND DISCUSSION}

\section{Optimization of the chromatographic conditions}

To optimize peak separation and achieve reproducible quality peak-shapes two chromatographic columns, several mobile phase systems, flow-rate programs and column temperatures were tested. Fluorescence and UV detectors are chosen as the most commonly used detectors for the analysis of tocopherols.

A reversed phase Zorbax Eclipse XDB C18 (rapid resolution $\mathrm{HT}, 1.8 \mu \mathrm{m}, 50 \mathrm{~mm} \times 4.6 \mathrm{~mm}$ ) analytical column with mobile phases of $100 \%$ methanol and $100 \%$ acetonitrile, at working temperature of $50{ }^{\circ} \mathrm{C}$ was initially tested for tocopherol separation. The flow rate was $1.6 \mathrm{ml} / \mathrm{min}$ and UV detection was set at $292 \mathrm{~nm}$. The results were not satisfactory because of the short chromatographic run, the small tocopherol concentration in some of the samples and the presence of large amounts of interfering compounds. All these factors caused a very weak peak resolution or absence of $\alpha$ tocopherol peak.

A longer reversed-phase analytical column Restek Ultra IBD C18 (150 $\mathrm{mm} \times 4.6 \mathrm{~mm}$ ) with a particle size of $5 \mu \mathrm{m}$ was also tested. The chromatographic separation was carried out at $30-50{ }^{\circ} \mathrm{C}$ with fluorescence (ex 295 $\mathrm{nm}$, em $330 \mathrm{~nm}$ ) and UV (292 and $286 \mathrm{~nm}$ ) detection. The different mobile phases with various proportions of solvents (methanol-water, $100 \%$ methanol, acetonitrile-water, $100 \%$ acetonitrile) at isocratic and gradient mode were tested. The best peak separation was obtained with $100 \%$ acetonitrile. Retention times on the Restek Ultra IBD C18 column, with a mobile phase of $100 \% \mathrm{ACN}$ and column temperature of $40{ }^{\circ} \mathrm{C}$ were $3.082 \mathrm{~min}$ for $\alpha$-tocopherol and $2.089 \mathrm{~min}$ for $\alpha$-tocopheryl acetate (Figure 1). These chromatographic conditions were found to be optimal for $\alpha$-tocopherol analysis. 


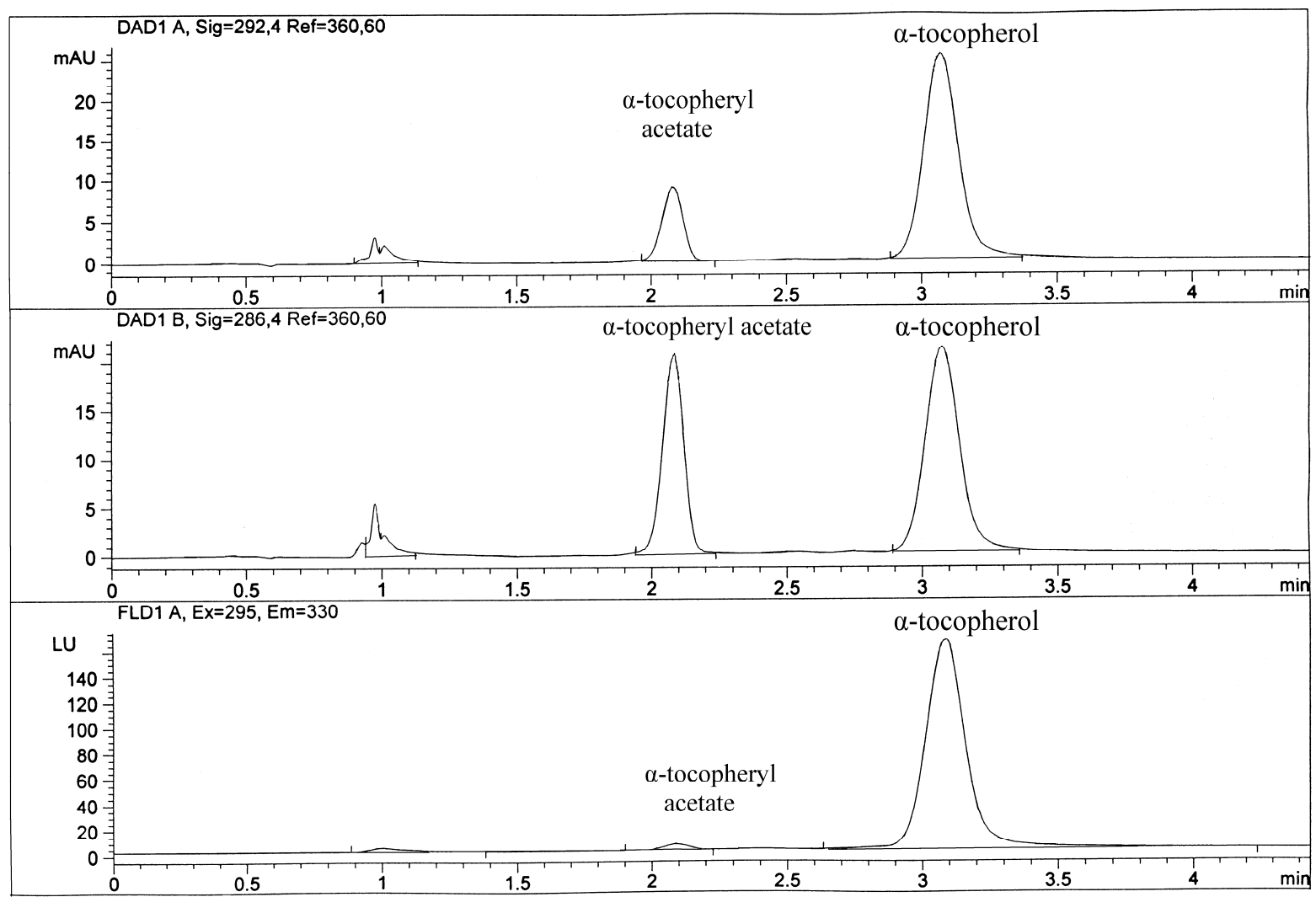

Figure 1. Chromatograms of standard solution containing both $\alpha$-tocopherol and $\alpha$-tocopheryl acetate on the Restek UItra IBD C18 analytical column with UV and fluorescence detection.

\section{Optimization of procedure for milk sample preparation}

Milk is a complex emulsion that contains proteins, antioxidants, vitamins, lipids, oligosaccharides and other biologically active substances. Unsupplemented milk contains natural $\alpha$-tocopherol associated with many other reducing substances. This type of sample is usually prepared by saponification of lipid residues followed by an extraction step [17], although the procedures without saponification were also proposed [18]. Traditional methods utilize different toxic reagents in quite high quantities, especially for the $\alpha$-tocopherol extraction. We adapted the previous reported techniques to our samples. Also we tried to use lower volumes of milk samples, reagents and organic solvents in order to develop green extraction method.

In our work, $\alpha$-tocopherol was determined in commercial, raw cow and raw goat milk. Considering that milk contains a large content of fat, it was necessary to apply a saponification procedure before extraction. In order to break lipid structures into which $\alpha$-tocopherol is bound, various saponification conditions $(10,30$ and $50 \% \mathrm{KOH}$ solutions) were tested. Milk samples were spiked with the same amount of $\alpha$-tocopherol, $\alpha$-tocopheryl acetate and $\alpha$-tocopherol $+\alpha$-tocopheryl acetate. Obtained spiked samples and two blank samples were further treated with mixture which consisted of $1 \mathrm{ml}$

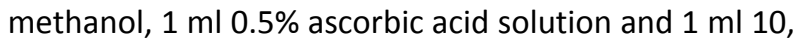
30 or $50 \% \mathrm{KOH}$ solution. For $10 \% \mathrm{KOH}$ a large peak of milk lipids at retention time of about 0.5 min was observed. Also, for the sample that was spiked only with $\alpha$-tocopheryl acetate two peaks corresponding to $\alpha$-tocopheryl acetate and $\alpha$-tocopherol were detected, and the intensity of the $\alpha$-tocopherol peak was higher than in non-spiked (blank) milk sample. When milk with $\alpha$ tocopherol $+\alpha$-tocopheryl acetate was treated with 30 and $50 \% \mathrm{KOH}$ peak of $\alpha$-tocopheryl acetate disappeared and the area of $\alpha$-tocopherol peak became higher, which indicates alkaline hydrolysis of esterified form and its transformation into $\alpha$-tocopherol. This was supported by the fact that when only $\alpha$-tocopheryl acetate was added to milk sample and the sample was further treated with 50 or $30 \% \mathrm{KOH}$, only the peak with retention time and UV spectrum corresponding to $\alpha$-tocopherol appeared. Therefore, higher concentrations of $\mathrm{KOH}$ solution enable determination of the total $\alpha$-tocopherols in a milk sample by using only one chromatographic peak. Simple assay for total available $\alpha$-tocopherol (natural plus supplemental) may be important because milk is often supplemented with $\alpha$-tocopheryl acetate, as was discussed in the introduction. The $30 \%$ $\mathrm{KOH}$ solution was finally selected for saponification. 
For precipitation of casein and whey proteins, absolute ethanol and methanol were tested. The milk samples were spiked with the same concentration of $\alpha$ tocopherol standard and treated with the same volume of either methanol or absolute ethanol. The area of the chromatographic peak for $\alpha$-tocopherol was higher when methanol was used for deproteinisation, so this solvent was selected for further work.

The final sample preparation procedure was: $1 \mathrm{ml}$ of methanol, $1 \mathrm{ml} 0.5 \%$ ascorbic acid and $1 \mathrm{ml} \mathrm{30 \%} \mathrm{KOH}$ were added in this order to $1 \mathrm{ml}$ of milk. After the sample was vigorously vortexed for $1 \mathrm{~min}$, the tube was left to rest in a water bath for $30 \mathrm{~min}$ at $70{ }^{\circ} \mathrm{C}$. After cooling of the reaction mixture, $4 \mathrm{ml}$ of diethyl ether was added to the tube. Then, the mixture was vortexmixed three times for $30 \mathrm{~s}$ while cooled on ice. The tube was then centrifuged at $3000 \mathrm{~g}$ for $10 \mathrm{~min}$ at 20 ${ }^{\circ} \mathrm{C}$. After centrifugation, $3 \mathrm{ml}$ of the upper diethyl ether layer was carefully pipetted in a new tube and evaporated up to dry in a stream of $\mathrm{N}_{2}$ at $40{ }^{\circ} \mathrm{C}$. The residue was re-dissolved in $1 \mathrm{ml}$ of absolute ethanol with heating and vortex mixing at $30{ }^{\circ} \mathrm{C}$. The obtained sample was filtered through an Econofilter 25/0.45 $\mu \mathrm{m} \mathrm{RC} \mathrm{(Agi-}$ lent Technologies) and after $30 \mathrm{~min} 20 \mu \mathrm{l}$ was injected into the column.

\section{Method validation}

The repeatability of the chromatographic measurements was evaluated using standard $\alpha$-tocopherol solutions at the concentration levels $0.4,0.7$ and $1.2 \mu \mathrm{g} / \mathrm{mL}$. For the repeatability, the standard solutions were analyzed five times in the same day. The relative standard deviations (RSD) were 3.3, 2.5 and $0.95 \%$, respectively. The extraction method was also validated taking into account precision and accuracy. Precision was assessed for three repeated extractions of the same milk sample and obtained RSD values were up to $6.0 \%$. The accuracy of the extraction method was evaluated by the standard addition procedure (percent of recovery). The standard of $\alpha$-tocopherol was added to the sample at three addition levels $(0.2,0.4$ and $0.5 \mu \mathrm{g} / \mathrm{mL})$ and whole extraction procedure was carried out. The yield of extraction stages was calculated based on the difference between the total amount of $\alpha$-tocopherol recovered from the spiked samples, the amount observed in the non-spiked samples and the amount of $\alpha$-tocopherol added [19]. The mean recoveries expressed as percentages were $78.5,86.7$ and $91.0 \%$ for three addition levels.

Table 1 presents the linearity range, limit of detection $(L O D)$ and limit of quantification $(L O Q)$ for $\alpha$-tocopherol at selected chromatographic conditions. Good linearity with high correlation coefficient was observed over the examined concentration range. The limit of detection was calculated as the concentration corresponding to three times the calibration error divided by the slope and the limit of quantification was calculated as the concentration corresponding to 10 times the calibration error divided by the slope.

Table 1. Analytical and statistical analysis of the calibration graph for $\alpha$-tocopherol determination; linearity range: $0.30-2.00 \mu \mathrm{g} / \mathrm{ml}$

\begin{tabular}{lc}
\hline Parameter & Value \\
\hline Number of points & 13 \\
Slope, ${\mathrm{ml} \mathrm{gg}^{-1}}^{\text {Intercept }}$ & 414.7 \\
Correlation coefficient & -120.1 \\
Standard error of the slope & 0.996 \\
Standard error of the intercept & 11.4 \\
Standard deviation of the fit & 13.1 \\
Limit of detection, $\mu \mathrm{gl}^{-1}$ & 21.7 \\
${\text { Limit of quantification, } \mathrm{\mu g} \mathrm{ml}^{-1}}$ & 0.09 \\
\hline
\end{tabular}

\section{$\alpha$-Tocopherol determination in milk samples}

The elution profile of $\alpha$-tocopherol in spiked and unspiked commercial cow milk are shown in Figure 2, and its UV spectra obtained by a diode array detector is depicted in Figure 3. The retention time for $\alpha$-tocopherol in samples was $3.04 \pm 0.04 \mathrm{~min}$ (inter-day precision). The peak of $\alpha$-tocopherol is symmetrical, providing accurate measurements of its concentration. Table 2 shows the results of $\alpha$-tocopherol determination in different types of milk. Data were reported as mean value \pm standard deviation for five different samples with the same fat content.

If these obtained values are compared with those in literature $(0.9 \mu \mathrm{g} / \mathrm{ml}$ in whole milk [20]), it can be seen that the content found experimentally in commercial milk from the Serbian market practically coincides with literature data. A very significant linear correlations $(p<$ $<0.01$ ) was determined between fat content and $\alpha$-tocopherol concentration ( $r=0.924)$. For example, UHT milk with $0.5 \%$ fat had $\alpha$-tocopherol concentration below $0.30 \mu \mathrm{g} / \mathrm{ml}$ which is more than three times lower than UHT samples with $3.2 \%$ milk fat (average 0.86 $\mu \mathrm{g} / \mathrm{ml})$, confirming that milk fat is an important component for fat-soluble vitamins. For the same fat content $(2.8 \%) \alpha$-tocopherol levels were higher in pasteurized (average $0.83 \mu \mathrm{g} / \mathrm{ml}$ ) than in UHT cow milk (average $0.69 \mu \mathrm{g} / \mathrm{ml}$ ), which indicates that some losses of vitamin still occur during processing or storage. Pasteurization and ultra high temperature (UHT) sterilization are different processing techniques of milk, but both involve heat treatment. UHT sterilization involves heating in the higher temperature range than pasteurization. Despite the numerous papers that report $\alpha$-tocopherol heat stability, our results show that for all investigated products pasteurized milk maintains more $\alpha$-tocopherol than UHT milk. 

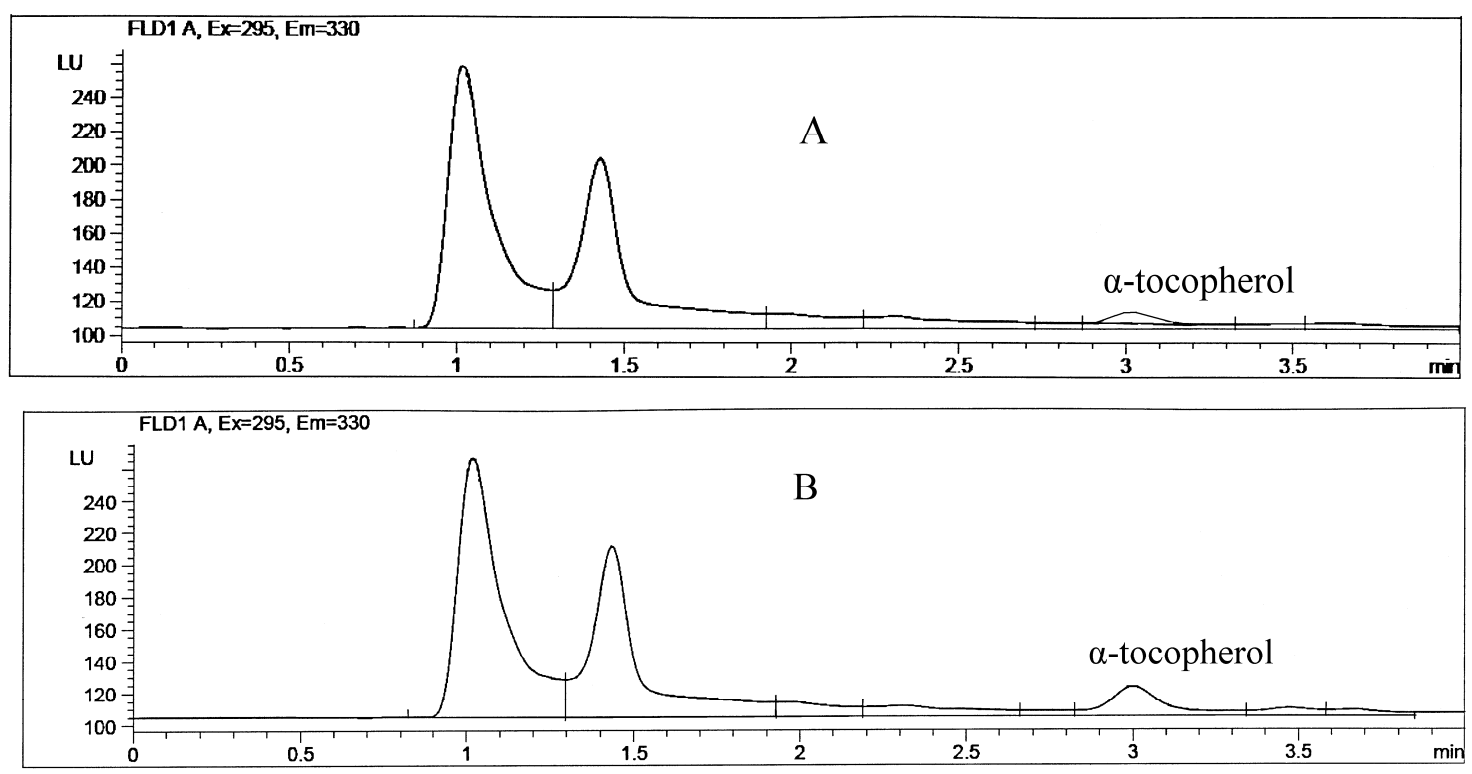

Figure 2. Chromatograms of unspiked (A) and spiked (B) commercial cow milk.

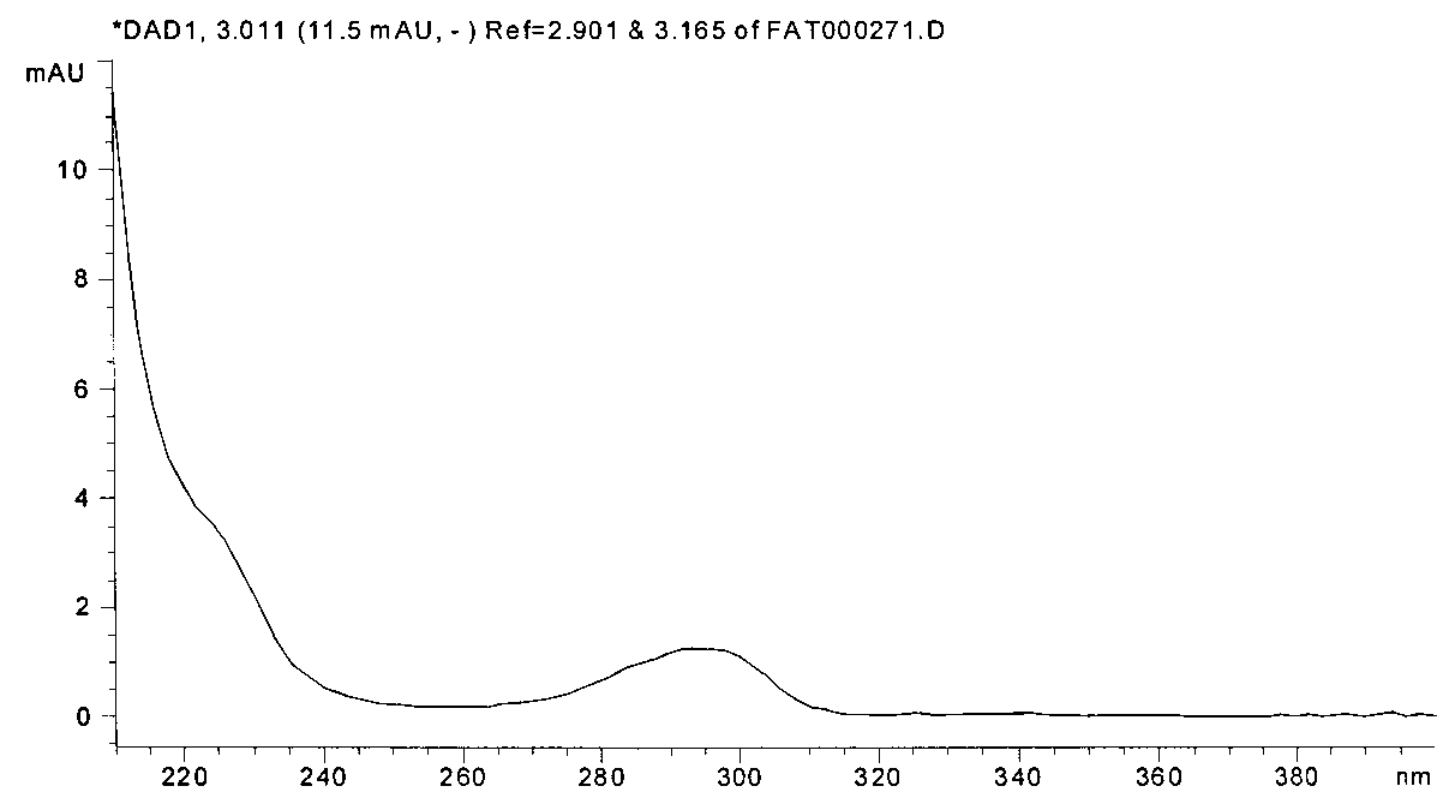

Figure 3. UV spectra of $\alpha$-tocopherol in cow milk sample.

Table 2. $\alpha$-Tocopherol content in different types of commercial and raw milk

\begin{tabular}{lccc}
\hline Type of milk & Fat content, $\%$ & Average $\alpha$-tocopherol concentration, $(x \pm S D) / \mu \mathrm{g} \mathrm{ml^{-1 }}$ & $R S D / \%$ \\
\hline UHT milk & $0.50 \pm 0.06$ & $<0.30$ & $>8.0$ \\
& $1.60 \pm 0.04$ & $0.45 \pm 0.018$ & 4.0 \\
& $2.80 \pm 0.04$ & $0.69 \pm 0.019$ & 2.8 \\
Pasteurized milk & $3.20 \pm 0.05$ & $0.86 \pm 0.012$ & 1.4 \\
& $0.50 \pm 0.07$ & $0.30 \pm 0.016$ & 5.3 \\
Raw cow milk & $1.60 \pm 0.05$ & $0.58 \pm 0.020$ & 3.5 \\
Raw goat milk & $2.80 \pm 0.05$ & $0.83 \pm 0.013$ & 1.6 \\
\hline
\end{tabular}


Raw cow and goat milk samples were obtained from a rural mountainous husbandry where households use natural animal feed, not those enriched with vitamins. It is known that fat-soluble vitamins content in raw milk varies widely with breed of animal, feed and stage of lactation. For the above-mentioned geographical area raw cow milk had slightly lower $\alpha$-tocopherol level than whole commercial milk. Besides the already mentioned factors, the reason for this may be the fact that producers often add $\alpha$-tocopherol as a preservative to commercial milk, which is not common in rural households.

Comparing the raw cow and raw goat milk from the same geographical area, we found that the $\alpha$-tocopherol content in goat milk was considerably higher than in cow milk. In raw milk the amount of $\alpha$-tocopherol is also in relation to content of milk fat. Therefore we found that raw goat milk with average fat content of $4.4 \%$ had $1.25 \mu \mathrm{g} / \mathrm{ml}$ of $\alpha$-tocopherol, while raw cow's milk with average milk fat content of $3.8 \%$ had $0.66 \mu \mathrm{g} / \mathrm{ml}$ of $\alpha$-tocopherol. Since the goat milk has twice as much $\alpha$-tocopherol, these data indicate higher nutritional value of goat milk with respect to $\alpha$-tocopherol content.

\section{CONCLUSION}

Cow milk is the most widely consumed food and in recent years there has been evidence that the consumption of milk and dairy products may confer additional benefits with respect to the diseases of ageing. Foods which contain components that have beneficial effects beyond those associated with the nutrient value are referred as "functional food" [21]. A number of these components have been identified in milk and dairy products [22]. Higher levels of bioactive materials in milk and technological procedure for its preparation may enhance its nutritive value, health qualities and physical characteristics. The fortification or enrichment of foods with various essential nutrients has been conducted for the purpose of nutritional need [23]. For that reason many manufacturers enrich milk by adding $\alpha$-tocopherol or $\alpha$-tocopheryl acetate. In contrast, during last decade there was an increased demand for low-fat or fat-free products. These dairy products have much less fat-soluble bioactive compounds. For such products it is especially important to monitor and maintain levels of lipophilic antioxidants such as $\alpha$-tocopherol.

This paper is, to our knowledge, the first study carried out the content of this very important vitamin in the commercial and raw milk from the Serbian market. The amounts of $\alpha$-tocopherol found in commercial milk are in agreement with those in literature. Since there is a significantly higher content of $\alpha$-tocopherol in goat milk, it would be important to increase the use of these types of milk in people's daily diet.

\section{Acknowledgements}

This research was supported by the Ministry of Education, Science and Technological Development of the Republic Serbia, Grant TR 31060.

\section{REFERENCES}

[1] G.W. Burton, K.U. Ingold, Autoxidation of biological molecules. 1. Antioxidant activity of vitamin $\mathrm{E}$ and related chain-breaking phenolic antioxidants in vitro, J. Am. Chem. Soc. 103 (1981) 6472-6477.

[2] Regulation (EC) No 1925/2006 of the European Parliament and of the Council of 20 December 2006 on the addition of vitamins and minerals and of certain other substances to foods, Official Journal of the European Union, L 404/26-38.

[3] C. Schneider, Chemistry and biology of vitamin E, Mol. Nutr. Food Res. 49 (2005) 7-30.

[4] Lj. Sretenović, S. Aleksić, M.P. Petrović, B. Miščević, Nutritional factors influencing improvement of milk and meat quality as well as productive and reproductive parameters of cattle, Biotechnology in Animal Husbandry 23 (5-6) (2007) 217-226.

[5] H.E. Indyk, Simplified saponification procedure for the routine determination of total vitamin $\mathrm{E}$ in dairy products, foods and tissues by high-performance liquid chromatography, Analyst 113 (1988) 1217-1221.

[6] M.M. Delgado Zamarreño, A. Sánchez Pérez, C. Gómez Pérez, J. Hernández Méndez, High-performance liquid chromatography with electrochemical detection for the simultaneous determination of vitamin $A, D_{3}$ and $E$ in milk, J. Chromatogr., A 623 (1992) 69-74.

[7] M.K. Balz, E. Schulte, H.-P. Thier, Simultaneous determination of $\alpha$-tocopheryl acetate, tocopherols and tocotrienols by HPLC with fluorescence detection in foods, Eur. J. Lipid Sci. Tech. 95 (1993) 215-220.

[8] S. Albalá-Hurtado, S. Novella-Rodriguez, M. Teresa Veciana-Nogués, Abel Mariné-Font, Determination of vitamins $A$ and $E$ in infant milk formulae by high-performance liquid chromatography, J. Chromatogr., A 778 (1997) 243-246.

[9] P. Salo-Vaananen, V. Ollilainen, P. Mattila, K. Lehikoinen, E. Salmela-Molsa, V. Piironen, Simultaneous HPLC analysis of fat-soluble vitamins in selected animal products after small-scale extraction, Food Chem. 71 (2000) 535-543.

[10] Ch. Turner, L. Mathiasson, Determination of vitamins A and $E$ in milk powder using supercritical fluid extraction for sample clean-up, J. Chromatogr., A 874 (2000) 275$-283$.

[11] J.W. DeVries, K.R. Silvera, Determination of vitamins A (retinol) and $E$ (alpha-Tocopherol) in foods by liquid chromatography: Collaborative study, J. AOAC Int. 85 (2002) 424-434.

[12] A. Ubaldi, G. Delbono, A. Fusari, P Serventi, Quick HPLC method to determine vitamin $\mathrm{E}$ concentration in cow's milk, Ann. Fac. Medic. Vet. di Parma XXV (2005) 101-110 . 
[13] O. Korchazhkina, E. Jones, M. Czauderna, S.A. Spencer, J. Kowalczyk, HPLC with UV detection for measurement of vitamin E in human milk, Acta Chromatogr. 16 (2006) 48-57.

[14] A. Escriva, M.J. Esteve, R. Farre, A. Frigola, Determination of liposoluble vitamins in cooked meals, milk and milk products by liquid chromatography, J. Chromatogr., A 947 (2002) 313-318.

[15] B. Rodas Mendoza, S. Morera Pons, A.I. Castellote Bargallo, M.C. Lopez-Sabater, Rapid determination by reversed-phase high-performance liquid chromatography of vitamins $A$ and $E$ in infant formulas, J. Chromatogr., A 1018 (2003) 197-202.

[16] AOAC Official Method 2000.18, Fat Content of Raw and Pasteurized Whole Milk Gerber Method by Weight, First Action 2000, Final Action 2004.

[17] C.J. Blake, Status of methodology for the determination of fat-soluble vitamins in foods, dietary supplements, and vitamin premixes, J. AOAC Int. 90 (2007) 897-910.
[18] M. Czauderna, J. Kowalczyk, Alkaline saponification results in decomposition of tocopherols in milk and ovine blood plasma, J. Chromatogr., B 858 (2007) 8-12.

[19] D.T. Burns, K. Danzer, A. Townshend, Use of the term "recovery" and "apparent recovery" in analytical procedures, Pure Appl. Chem. 74 (2002) 2201-2205.

[20] P.F. Fox, P.L.H. McSweeney, Dairy Chemistry and Biochemistry, First edition, Blackie Academic and Professional, Thomson Science, UK, 1998.

[21] A.L. Lock, D.E. Bauman, Dairy products and milk fatty acids as functional food components, Proceedings of the Cornell Nutrition Conference, 2003, pp. 159-173.

[22] Z.F. Bhat, H. Bhat, Milk and dairy products as functional foods: A review, Int. J. Dairy Sci. 6 (2011) 1-12.

[23] N.S. Kwak, D.J. Jukes, Functional foods. Part 2: the impact on current regulatory terminology, Food Contr. 12 (2001) 109-117. 


\section{IZVOD}

\section{ODREĐIVANJE SADRŽAJA $\alpha$-TOKOFEROLA U KRAVUEM I KOZIJEM MLEKU SA SRPSKOG TRŽIŠTA}

Slavica Sunarić ${ }^{1}$, Jelena Živković ${ }^{1}$, Radmila Pavlović ${ }^{1}$, Gordana Kocić ${ }^{2}$, Nataša Trutić ${ }^{1}$, Slavoljub Živanović ${ }^{3}$

${ }^{1}$ Univerzitet u Nišu, Medicinski fakultet, Katedra za hemiju, Niš, Srbija

${ }^{2}$ Univerzitet u Nišu, Medicinski fakultet, Katedra za biohemiju, Niš, Srbija

${ }^{3}$ Univerzitet u Nišu, Medicinski fakultet, Laboratorija za hromatografiju, Niš, Srbija

(Naučni rad)

Vitamin $\alpha$-tokoferol je rastvoran u mastima i spada u jake antioksidanse koji se unose hranom. U ljudskoj ishrani značajan izvor ovog vitamina su mleko i mlečni proizvodi. $U$ tehnološkom procesu proizvodnje mleka, $\alpha$-tokoferol se uglavnom dodaje iz dva razloga: da bi se povećala hranljiva vrednost mleka (obogaćivanje) ili da bi se sprečio proces oksidacije mlečnih masti, tj. užeglost i time produžila trajnost proizvoda (aditiv). Odredba (EC) No 1925/2006 Evropskog parlamenta i Saveta dozvoljava primenu $\alpha$-tokoferola, $\alpha$-tokoferil-acetata i $\alpha$-tokoferil-sukcinata kao aditiva prehrambenim namirnicama, pri čemu se zbog veće stabilnosti najčešće koristi $\alpha$-tokoferil-acetat. Cilj našeg rada bio je određivanje i poređenje sadržaja $\alpha$-tokoferola u komercijalnom (pasterizovanom i UHT) neobogaćenom kravljem mleku glavnih domaćih proizvođača, kao i u neprerađenom kravljem i kozijem mleku sa gazdinstava u okolini Niša. Svi uzorci mleka pripremani su postupkom alkaline saponifikacije $(30 \% \mathrm{KOH})$ i denaturacije lipoproteina metanolom, a zatim je $\alpha$-tokoferol izdvojen tečno-tečnom ekstrakcijom pomoću dietil-etra. Pri ovakvim saponifikacionim uslovima, prisutni $\alpha$-tokoferil-acetat hidrolizuje dajući $\alpha$-tokoferol, pa se na taj način može odrediti ukupni sadržaj $\alpha$-tokoferola $u$ ispitivanim uzorcima mleka. Određivanje $\alpha$-tokoferola izvršeno je na HPLC aparatu primenom reverzno-fazne C18 analitičke kolone. Detekcija je izvršena pomoću UV detektora (na talasnim dužinama 286 i $292 \mathrm{~nm}$ ) i fluorescentnog detektora (ex 295 $\mathrm{nm}$, em $330 \mathrm{~nm}$ ). Zbog veće osetljivosti i selektivnosti za dalji rad je izabran fluorescentni detektor. Mobilne faze je sadržala samo acetonitril. Za izabrane hromatografske uslove granica detekcije i kvantifikacije za $\alpha$-tokoferol iznosila je 0,09 i 0,30 $\mu \mathrm{g} / \mathrm{ml}$. Prinos ekstrakcije bio je 78,5, 86,7 i 91,0\% za tri odabrane koncentracije standardnog dodatka. Preciznost određivanja se nalazila u zadovoljavajućim okvirima $(R S D<6 \%)$ za većinu uzoraka. Rezultati analize su pokazali da je prosečni sadržaj $\alpha$-tokoferola u komercijalnom mleku sa vrlo niskim sadržajem mlečnih masti manji od $0,30 \mu \mathrm{g} / \mathrm{ml}$, dok je u punomasnom mleku taj interval $0,83-0,86 \mu \mathrm{g} / \mathrm{ml}$. Dobijeni podaci su u saglasnosti sa literaturnim vrednostima, na osnovu čega se može zaključiti da je u pogledu sadržaja ovog vitamina komercijalno mleko sa domaćeg tržišta zadovoljavajućeg kvaliteta. lako poslednjih godina postoji trend pravljenja niskomasnih i bezmasnih mleka i mlečnih proizvoda, ne treba izgubiti iz vida da kod takve vrste proizvoda količina bioaktivnih komponenti rastvornih u mastima može biti znatno smanjena. Naši rezultati pokazuju da je sadržaj $\alpha$-tokoferola u niskomasnom mleku čak 3-4 puta manji od onog u mleku sa većim procentom masti. Upoređivanjem sadržaja $\alpha$-tokoferola u mleku različitih životinja našli smo da neprerađeno kozije mleko ima znatno više ovog vitamina u odnosu na komercijalno i sirovo kravlje mleko, što ukazuje na značajnu nutritivnu karakteristiku ovog tipa mleka.

Ključne reči: $\alpha$-Tokoferol $\bullet$ Kravlje mleko - Kozije mleko • HPLC analiza 